\title{
FAKTOR-FAKTOR YANG BERHUBUNGAN DENGAN KEAKTIFAN KADER COMMUNTY TB CARE 'AISYIYAH SURAKARTA
}

\author{
Ika Arni Anisah ${ }^{1}$, Yuli Kusumawati ${ }^{2}$, Badar Kirwono ${ }^{3}$ \\ ${ }^{1}$ Community TB-HIV Care Aisyiyah Kudus. J1. K.H Noor Hadi No. 32. Janggalan \\ Kudus. Email: ${ }^{1}$ ikaanisa@gmail.com \\ ${ }^{2}$ Program Studi Kesehatan Masyarakat Fakultas Ilmu Kesehatan Universitas \\ Muhammadiyah Surakarta. Jl. A. Yani, Pabelan, Kartasura, Surakarta. \\ Email:²yuli.kusumawati@ums.ac.id \\ ${ }^{3}$ Kantor Kesehatan Pelabuhan Semarang
}

\begin{abstract}
ABSTRAK
Tuberkulosis (TB) merupakan salah satu infeksi menular yang diperlukan kerjasama lintas sektor dan organisasi masyarakat dalam upaya pemberantasannya. Organisasi 'Aisyiyah mengambil peran dengan membentuk kader Community TB Care 'Aisyiyah yang diharapkan untuk aktif menanggulangi persebaran TB. Penelitian ini bertujuan untuk mengetahui faktor-faktor yang berhubungan dengan keaktifan kader Community TB Care 'Aisyiyah Surakarta. Jenis penelitian ini merupakan penelitian observasional analitik dengan rancangan penelitian cross sectional. Populasi dalam penelitian ini adalah seluruh kader Community TB Care 'Aisyiyah Surakarta. Pengambilan sampel menggunakan teknik exhaustive sampling yaitu dengan mengambil semua objek dari populasi sebanyak 46 kader. Uji statistik menggunakan chi square dengan taraf kepercayaan 95\%. Hasil penelitian menunjukkan bahwa tidak ada hubungan antara pengetahuan dengan keaktifan kader $(\mathrm{p}=1,000)$, ada hubungan antara keikutsertaan di 'Aisyiyah dengan keaktifan kader $(\mathrm{p}=0,040)$, tidak ada hubungan status sosial ekonomi dengan keaktifan kader $(\mathrm{p}=0,155)$, tidak ada hubungan antara lingkungan keluarga dengan keaktifan kader $(\mathrm{p}=1,000)$, dan tidak ada hubungan antara lingkungan kerja dengan keaktifan kader Community TB Care 'Aisyiyah Surakarta $(\mathrm{p}=1,000)$.
\end{abstract}

Kata kunci: Community TB Care 'Aisyiyah, keaktifan kader, tuberkulosis

\begin{abstract}
Tuberculosis (TB) is one of the infectious diseases that need crosssectoral cooperation and community organizations in efforts to eradicate it. The organization 'Aisyiyah took on the role of forming Community TB Care' Aisyiyah cadres who are expected to actively tackle the spread of TB. This study aimed to determine the factors associated with the activity of Community TB Care cadres' Aisyiyah Surakarta. The type of research was an observational analytic study with the cross-sectional design. Population in the research was all cadre of Community TB Care 'Aisyiyah Surakarta. Sampling using
\end{abstract}


exhaustive sampling technique was to take all objects from the population of 46 cadres. The statistical test used was chi-square with 95\% confidence level. The results showed that there was no correlation between knowledge with the activeness of cadres ( $\mathrm{p}=$ 1.000), there was a relationship between participation in 'Aisyiyah with cadre activity $(\mathrm{p}=0.040)$, there was no socioeconomic status relationship with cadre activeness $(\mathrm{p}=0.155)$, there was the relation between family environment with the cadre activity $(\mathrm{p}=1.000)$, and there was no relation between working environment with the activity of cadre of Community TB Care 'Aisyiyah Surakarta $(p=1.000)$.

Keywords: Community TB Care 'Aisyiyah, activeness cadre, tuberculosis

\section{PENDAHULUAN}

Tuberkulosis (TB) merupakan salah satu infeksi menular disebabkan oleh bakteri Mycobacterium tuberculosisyang menginfeksi berbagai organ terutama pada paru-paru. Ketidakpatuhan meminum obat pada penyakit ini dapat menyebabkan Multi Drug Resistant (MDR) dan komplikasinya dapat mengakibatkan kematian. Perkembangan TB secara global dalam hal kemajuan dan pengendalian dimulai sejak 2 abad terakhir (Kemenkes, 2015).

Penyakit Tuberkulosis tidak bisa dianggap sebagai hal ringan. World Health Organization (2015), memcatat sebanyak 9,6 juta kasus baru TB pada tahun 2014. Sejumlah kasus tersebut terdiri dari 5,4 juta orang, 3,2 juta perempuan dan 1,0 juta anak, yang menjadikannya TB sebagai penyakit menular pembunuh terbesar di dunia. Bahkan yang sangat memprihatinkan, setelah beberapa tahun terakhir Indonesia menempati posisi urutan 3 dan 4 dengan kasus penyakit TB terbesar di duniadan pada tahun 2015 lalu WHO kembali merilis bahwa Indonesia menempati rangking ke-2 setelah India dengan angka $10 \%$ dari total global TB (WHO, 2015).

Dalam Berita Komunitas Peduli TB Community TB Care 'Aisyiyah (2014), setiap tahun di Indonesia diperkirakan 150 ribu dari 460 ribu penderita $\mathrm{TB}$ atau sekitar 5\% dari populasi TB dunia belum tertangani atau terjangkau pengobatan. Hal ini semakin serius, mengingat $1 \%$ pasien TB yang tidak tertangani dapat menularkan TB kepada 15 orang yang sehat.

Rencana Pembangunan Jangka Menengah Nasional 2015-2019, mencatat bahwa prevalensi TB di Indonesia tahun 2013-2014 per 100.000 penduduk sebanyak 660 dengan interval tingkat kepercayaan 95\% sebanyak 523-813. Menurut data Profil Kesehatan Jawa Tengah (2012), prevalensi TB penduduk Provinsi Jawa Tengah tahun 2012 sebesar 106,42 per 100.000 orang. Capaian CDR (Case Detection Rate) di Jawa Tengah tahun 2008 s/d 2012 tercatat masih dibawah target $100 \%$ yang telah ditetapkan. Hal ini juga didukung dengan angka kesembuhan (Cure Rate) yang terbukti belum mencapai target $90 \%$ dan terus mengalami penurunan tiap tahunnya.

Fenomena ini tidak jauh beda dengan data dari Dinas Kesehatan Kota Surakarta yang mencatat penemuan kasus TB Parudengan BTA (+) di tahun 2010 sebanyak 425 orang, tahun 2011 sebanyak 405 orang, tahun 2012 sebanyak 376 orang, tahun 2013 sebanyak 365 orang, tahun 2014 sebanyak 80 orang, dan di tahun 2015 sebanyak 376 orang. Dari data penemuan TB sejak tahun 2010 sampai 
2015 menunjukkan belum tercapainya target yakni sebesar 536 penemuan kasus TB dengan BTA (+). Demikian juga dengan target angka kesembuhan (Cure Rate) yang terbukti belum mencapai target 98\% yang telah ditetapkan (Dinkes Surakarta, 2015).

Seiring belum tercapainya target pemerintah dalam upaya mengatasi persebaran kasus TB dengan memberikan otonomi kepada kabupaten melalui strategi DOTS (Direcly Observed Treatment, Shourcourse chemotherapy) yang difokuskan pada penemuan dan penyembuhan pasien,sejauh ini terbukti belum berjalan optimal. Masalah ini memerlukan kerjasama lintas sektor fasilitas pelayanan kesehatan(fasyankes) dan organisasi yang berbasis masyarakatseperti lembaga swadaya masyarakat (LSM), komunitas dan lainlain yang turut aktif dalam mendukung strategi Global Stop TB Partnership (Amiruddin dkk, 2013).

Menurut Moeloek dalam berita komunitas peduli TB (2015), organisasi masyarakat mampu menjadi partner pemerintah dalam membantu pengentasan TB terutama upaya penemuan suspek dan menjadi PMO dalam menekan prevalensi MDR-TB (Multi Drugs Resisten Tuberculosis). Adapun salah satu organisasi masyarakat yang berpartisipasi pada program pemerintah dalam upaya pemberantasan TB yaitu organisasi 'Aisyiyah.

'Aisyiyah dalam program penanggulangan $\mathrm{TB}$ memiliki komunitas khusus yang disebut Community TB Care 'Aisyiyah berpusat di Jakarta dan memperoleh bantuan dari The Global Fundsebagai penerima dana sekunder dari Principal Recipient (PR). Program Community TB Care'Aisyiyah dilaksanakan di 30 Propinsi wilayah 'Aisyiyah salah satunya Propinsi Jawa Tengah, khususnya di Kota Surakarta dengan melibatkan beberapa kader yang terlatih disetiap wilayah kerjanya sebagai salah satu kunci keberhasilan program (Pincipal Recipient TB Care'Aisyiyah, 2014).

Seorang kader Community TB Care'Aisyiyah dilatih untuk memiliki kompetensi antara lain: (1), melakukan penyuluhan TB; (2), mencari terduga TB; (3), mendampingi terduga untuk periksa dahak; (4), memantau pengobatan TB pasien; (5), membina PMO; (6), mencatat dan melaporkan data pasien TB; (7), informasi penting tentang TB, (Principal Recipient TB Care 'Aisyiyah, 2014).

Berdasarkan survei pendahuluan yang dilakukan di kantor Community TB Care 'Aisyiyah Surakarta didapatkan hasil bahwa sejak bulan Juli 2014 sampai Oktober 2015 ditemukan suspek dengan BTA (+) sejumlah 19 orang yang telah dirujuk ke fasilitas pelayanan kesehatan setempat.Terdapat 47 nama kader Community TB Care 'Aisyiyah yang terdaftar dan mengikuti proses pelatihan, namun pada kiprahnya hanya $40 \%$ kader yang aktif berkontribusi, serta satu diantaranya telah meninggal dunia di bulan November 2015. Ketidakaktifan kader sangat menentukan dalam upaya pencapaian target penemuan suspek TB yang telah ditetapkan oleh Global Found sebanyak 340 suspek per semester.

Data sekunder dari Community TB Care 'Aisyiyah menunjukkan sejak 1 Januari 2014 sampai akhir tahun 2015 Community TB Care 'Aisyiyah Surakarta hampir melampaui 4 semester. Pada semester pertama dan kedua Community TB Care 'Aisyiyah Surakarta mendapat rapor merah dengan angka penemuan suspek yang jauh dari target. Pada semester ketiga penemuan suspek meningkat menjadi $75 \%$ target, dan pada semester 4 ini masih dalam proses pengupayaan.

Penemuan suspek TB yang jauh dari target menjadi kekhawatiran tersendiri bagi Community TB Care 'Aisyiyah, 
selain menjadi indikasi adanya perkembangan kuman yang makin banyak, peningkatan penularan $\mathrm{TB}$, dan komplikasi dampak, juga sebagai laporan pencapaian.Laporan ini yang kedepannyaakan menjadi bahan evaluasi oleh The Global Found dalam menjalin hubungan kerjasama terkhusus dalam hal pendanaan bagi upaya penanggulangan TB di Indonesia.

Membaca dari fakta lapangan dan jurnal penelitian Amiruddin dkk. (2013), mengenai pelaksanaan advokasi, komunikasi, dan mobilisasi sosial (AKMS) oleh 'Aisyiyah menyarankan adanya penelitian lanjutan mengenai faktor penyebab keaktifan kader. Oleh karenanya, peneliti tertarik untuk melakukan penelitian lanjutan yang bertujuan untuk mengetahui faktor-faktor yang berhubungan dengan keaktifan kader Community TB Care 'Aisyiyah di Kota Surakarta.

\section{METODE PENELITIAN}

Jenis penelitian ini adalah observasional analitik dengan rancangan cross sectional study. Penelitian ini dilaksanakan pada bulan Juni 2016 di Kantor Community TB Care 'Aisyiyah Kota Surakarta.Populasi pada penelitian ini adalah seluruh kader Community TB Care 'Aisyiyah di Kota Surakarta terhitung sejak tahun 2014 sampai bulan Januari 2016 yang telah mengikuti pelatihan kader yaitu sebanyak 46 orang. Pengambilan sampel pada penelitian ini menggunakan teknik exhaustive sampling yaitu sebanyak 46 kader Community TB Care 'Aisyiyah Surakarta sebagai sampel penelitian.

Analisis univariat digunakan untuk mendeskripsikan masing-masing variabel dengan distribusi frekuensi atau proporsi. Analisis bivariat digunakan untuk membuktikan hipotesis hubungan antara variabel bebas yang meliputi pengetahuan, keikutsertaan di 'Aisyiyah, status sosial ekonomi, lingkungan keluarga, lingkungan kerja, dengan variabel terikat yaitu keaktifan kader Community TB Care 'Aisyiyah menggunakan uji Chi-square.

\section{HASIL DAN PEMBAHASAN}

\section{Karakteristik Responden}

Gambaran karakteristik kader berdasarkan umur, jenis kelamin, angkatan kader, pekerjaan dan pendidikan. Sebanyak 32 kader $(69,5 \%)$ tidak aktif dan 14 kader $(30,5 \%)$ yang aktif. Adapun karakteristik umur kader paling banyak $(63,0 \%)$ yaitu pada rentang 45-54 tahun dan paling sedikit $(6,5 \%)$ berada pada rentang 65-74 tahun. Distribusi responden berdasarkan jenis kelamin sebagian besar perempuan (91,3\%). Berdasarkan tahun angkatan terdaftar menjadi kader, dari seluruh kader yang ada, 56,5\% berasal dari angkatan 2014 dan 43,5\% dari angkatan 2015. Berdasarkan karakteristik pekerjaan sebagian besar $(60,9 \%)$ tidak bekerja atau sebagai ibu rumah tangga. Distribusi responden berdasarkan tingkat pendidikan, paling banyak adalah tamatan SMA/sederajat $(58,7 \%)$ dan paling sedikit $(10,9 \%)$ adalah tamatan SD/ tidak sekolah.

\section{Analisis Univariat}

Gambaran tentang pengetahuan, keikutsertaan di 'Aisyiyah, status sosial ekonomi, lingkungan keluarga, dan lingkungan kerja ditampilkan pada Tabel 1 berikut. 
Tabel 1. Distribusi Frekuensi menurut Pengetahuan, Keikutsertaan 'Aisyiyah, Status Sosial Ekonomi, Lingkungan Keluarga, dan Lingkungan Kerja.

\begin{tabular}{lcc}
\hline \multicolumn{1}{c}{ Variabel } & \multicolumn{2}{c}{ Total } \\
\cline { 2 - 3 } & $\mathbf{N}$ & $\mathbf{( \% )}$ \\
\hline Pengetahuan & 4 & 8,7 \\
Kurang Baik & 42 & 91,3 \\
Baik & & \\
Keikutsertaan di `Aisyiah & 22 & 47,8 \\
$\quad$ Tidak ikut & 24 & 52,2 \\
$\quad$ Ikut & 37 & 80,4 \\
Status Sosial Ekonomi & 9 & 19,6 \\
$\quad$ Rendah, sedang & & \\
$\quad$ Tinggi & 15 & 32,6 \\
Lingkungan keluarga & 31 & 67,4 \\
$\quad$ Kurang & & \\
Baik & 27 & 58,7 \\
Lingkungan kerja & 19 & 41,3 \\
$\quad$ Kurang & \multicolumn{3}{c}{ Baik } &
\end{tabular}

Hasil analisis univariat menunjukkan kader Community TB Care 'Aisyiyah Surakarta hampir seluruhnya memiliki pengetahuan yang baik tentang penyakit TB $(91,3 \%)$. Pengetahuan kader ini meliputi tentang TB baik penyebab, penularan, gejala, pengobatan, dan pencegahan. Keikutsertaan dalam hal
'Aisyiyah sebagian kader (52,2\%) ikut di 'Aisyiyah baik secara struktural ataupun mengikuti kajian dan sebagian kecil $(47,8 \%)$ kader tidak ikut 'Aisyiyah. Hasil penelitian menunjukkan sebagian besar kader berstatus sosial ekonomi rendah hingga sedang $(80,4 \%)$, dan untuk status sosial ekonomi tinggi hanya sebagian kecil (19,6\%). Terkait dengan lingkungan keluarga, $67,4 \%$ kader berada pada lingkungan keluarga yang baik dan 32,6\% berada pada lingkungan keluarga yang kurang baik. Berdasarkan lingkungan kerja kader Community TB Care 'Aisyiyah Surakarta sebagian besar $(58,7 \%)$ merasa berada pada lingkungan kerja kurang baik dan sebagian kecil $(41,3 \%)$ merasa berada pada lingkungan kerja yang baik. Variabel lingkungan kerja ini berkaitan dengan sarana prasarana serta hubungan antar rekan kerja kader Community TB Care 'Aisyiyah Surakarta.

\section{Analisis Bivariat}

Hasil analisis bivariat dari masingmasing variabel bebas dan variabel terikat yang dapat dilihat pada Tabel 2 berikut.

Tabel 2. Hubungan Pengetahuan, Keikutsertaan di 'Aisyiyah, Status Sosial Ekonomi, Lingkungan Keluarga, Lingkungan Kerja, dengan Keaktifan Kader Community TB Care 'Aisyiyah Surakarta

\begin{tabular}{|c|c|c|c|c|c|c|c|}
\hline \multirow{3}{*}{ Variabel } & \multicolumn{4}{|c|}{ Keaktifan Kader } & \multirow{2}{*}{\multicolumn{2}{|c|}{ Total }} & \multirow{3}{*}{ P Value } \\
\hline & \multicolumn{2}{|c|}{ Kurang } & \multicolumn{2}{|c|}{ Aktif } & & & \\
\hline & $\mathbf{n}$ & $(\%)$ & n & $(\%)$ & $\mathbf{n}$ & $(\%)$ & \\
\hline \multicolumn{8}{|l|}{ Pengetahuan } \\
\hline Kurang & 3 & 75 & 1 & 25 & 4 & 100 & \multirow{2}{*}{1,000} \\
\hline Baik & 29 & 69 & 13 & 31 & 42 & 100 & \\
\hline \multicolumn{8}{|l|}{ Keikutsertaan } \\
\hline Tidak ikut & 19 & 86,4 & 3 & 13,6 & 22 & 100 & \multirow{2}{*}{0,040} \\
\hline Ikut & 13 & 54,2 & 11 & 45,8 & 24 & 100 & \\
\hline \multicolumn{8}{|c|}{ Status Sosial Ekonomi } \\
\hline Sedang & 28 & 75,7 & 9 & 24,3 & 37 & 100 & \multirow{2}{*}{0,155} \\
\hline Tinggi & 4 & 44,4 & 5 & 55,6 & 9 & 100 & \\
\hline \multicolumn{8}{|c|}{ Lingkungan keluarga } \\
\hline Kurang & 10 & 66,7 & 5 & 33,3 & 15 & 100 & \multirow{2}{*}{1,000} \\
\hline Baik & 22 & 71 & 9 & 29 & 31 & 100 & \\
\hline \multicolumn{8}{|l|}{ Lingkungan kerja } \\
\hline Kurang & 19 & 70,4 & 8 & 29,6 & 27 & 100 & \multirow{2}{*}{1,000} \\
\hline Baik & 13 & 68,4 & 6 & 31,6 & 19 & 100 & \\
\hline
\end{tabular}

Sumber: Data Primer Terolah Juli 2016 
Hubungan Pengetahuan dengan Keaktifan Kader Community TB Care $^{6}$ Aisyiyah Surakarta

Tabel 2 menunjukkan tidak ada hubungan antara pengetahuan dengan keaktifan kader Community TB Care 'Aisyiyah Surakarta $(\mathrm{p}=1,000)$. Sebagian besar kader sudah memiliki pengetahuan baik karena setelah responden direkrut menjadi kader, mereka langsung mendapatkan pelatihan menjadi kader serta mendapatkan buku panduan kader tentang tuberkulosis. Sehingga pengetahuan tidak bisa dijadikan sebagai daya ungkit adanya perubahan perilaku keaktifan kader Community TB Care 'Aisyiyah Surakarta.

Pengetahuan dalam kajian teoritik merupakan domain sangat penting dalam mempengaruhi tindakan seseorang, pada kaitan ini pengetahuan yang dimiliki kader kesehatan akan menentukan aktifitasnya dalam pengendalian kasus tuberkulosis (Notoatmojo, 2005). Teori tersebut sejalan dengan penelitian Wijaya dkk. (2013), yang menyimpulkan adanya hubungan yang signifikan antara pengetahuan dengan aktivitas kader kesehatan, dimana pengetahuan tinggi memiliki kemungkinan 18 kali lebih besar dalam pengendalian kasus tuberkulosis dari pada pengetahuan yang rendah ( $p$ value $=0,012)$. Berbeda dengan penelitian Suryati (2013), yang menyimpulkan hasil analisa tidak adanya hubungan antara pengetahuan dengan keaktifan kader posyandu ( $p$ value $=0,364)$, walaupun demikian kader dengan pengetahuan yang rendah tetap aktif berkontribusi dan turut memberikan pelayanan kesehatan di posyandu. Sejalan dengan penelitian dari Suryanti, penelitian Farhat (2012), yang menyatakan tidak adanya hubungan tingkat pengetahuan dengan keaktifan kader ( $p$ value $=0,227)$, dengan prevalensi responden kurang aktif lebih tinggi pada tingkat pengetahuan yang kurang sebesar 1,67 kali dibandingkan dengan pengetahuan bagus. Hal ini bisa terjadi karena seorang kader yang berperilaku tertentu dalam mewujudkan keaktifannya tidak semata-mata karena faktor pengetahuan, kadang disebabkan adanya dukungan atau motif yang mampu menggerakkan hati agar berbuat sesuatu yang berbeda, tergantung pengetahuan, pengalaman dan latar belakang pendidikan.

Menyinggung aspek latar belakang pendidikan, Hasil penelitian ini menunjukkan karakteristik kader Community TB Care 'Aisyiyah Surakarta baik kader yang aktif maupun yang kurang aktif paling banyak yaitu lulusan SMA (58,7\%). Menurut penelitian Indrawan dan Chatarina (2014), menyimpulkan bahwa pendidikan tidak selamanya berdampak pada pengambilan keputusan dalam berperilaku, dimana faktor lingkungan sekitar dan juga pengalaman menjadi faktor yang mampu mempengaruhi seseorang untuk berperan aktif menjadi kader.

\section{Hubungan Keikusertaan Di 'Aisyiyah dengan Keaktifan Kader Community TB Care 'Aisyiyah Surakarta}

Ada hubungan antara keikutsertaan di 'Aisyiyah dengan keaktifan kader Community TB Care 'Aisyiyah Surakarta $(\mathrm{p}=0,040)$. Keikutsertaan kader di 'Aisyiyah meliputi keanggotaan, jabatan struktural di 'Aisyiyah dan partsipasi dalam mengikuti kajian. Berdasarkan jawaban responden menunjukkan hanya sebagian kader $(54,3 \%)$ yang menjabat di struktural sebagai pengurus 'Aisyiyah. Keikutsertaan kader di 'Aisyiyah mampu memberikan efek positif bagi keaktifan kader, sebab kader akan sering bertatap muka dengan pengurus 'Aisyiyah sehingga cenderung mendapat informasi dan dukungan secara emosional untuk lebih aktif menjadi kader.

Hasil tersebut sejalan dengan Suhat dan Ruyatul (2014), dalam penelitianya 
yang menunjukkan adanya hubungan antara keikutsertaan kader pada organisasi lain dengan keaktifan kader dalam kegiatan posyandu di wilayah kerja puskesmas Palasari Kecamatan Ciater Kabupaten Subang $(p$ value $=0,00)$ dengan $\mathrm{OR}=17,57$. Kader yang mengikuti organisasi cenderung lebih bertanggungjawab dalam kegiatan organisasi termasuk dalam kegiatan posyandu. Ketidakikutsertaan ini juga berhubungan dengan rendahnya informasi, komunikasi interpersonal, dan juga kesibukan pekerjaan. Menurut Hongsragon (2016), proses komunikasi mampu menambah pemahaman pada norma sosial, yang perkembangannya akan membentuk hubungan rasa memahami dan membentuk kelompok bermoral dalam menjalankan norma sosial.

Menyinggung kesibukan pekerjaan, maka dalam karakteristik pekerjaan responden yang tidak bekerja atau ibu rumah tangga banyak yang aktif menjadi kader Community TB Care 'Aisyiyah Surakarta. Hasil penelitian ini sejalan dengan penelitian Farhat (2012), yang menyimpulkan bahwa responden tidak bekerja lebih memiliki waktu luang untuk lebih aktif melakukan kegiatan di posyandu. Namun, simpulan tersebut berbeda dengan simpulan penelitian dari Suhat dan Ruyatul (2014), yang menyatakan kader tidak bekerja akan dihadapkan pada penghasilan yang kurang dibandingkan dengan kader yang bekerja, sehingga kader akan berusaha semaksimal mungkin untuk mendapatkan pekerjaan yang akan menjamin kelangsungan hidupnya dengan mengabaikan kebutuhan sosial seperti menjadi kader kesehatan.

Hubungan Status Sosial Ekonomi dengan Keaktifan Kader Community TB Care 'Aisyiyah Surakarta

Tidak ada hubungan antara status sosial ekonomi dengan keaktifan kader
Community TB Care 'Aisyiyah Surakarta $(\mathrm{p}=0,155)$. Hasil ini bertentangan dengan penelitian Mintjelungan (2011), yang menggunakan metode korelasional dimana terdapat hubungan positif antara status sosial ekonomi dengan prestasi belajar mahasiswa dengan koefisien korelasi sebesar 0,54. Berbeda lagi dengan penelitian Anggraini (2015), yang menyimpulkan tidak terdapat hubungan antara status sosial ekonomi dengan keaktifan ibu dalam kegiatan posyandu ( $p$ value $=0,912$ ).

Menurut Sari (2015), status sosial ekonomi seperti halnya 2 cabang ilmu yang berbeda, namun diantara keduanya sebenarnya terdapat kaitan yang erat, salah satu kasusnya jika keperluan ekonomi tidak terpenuhi maka akan menimbulkan dampak sosial di masyarakat. Dampak sosial dimasyarakat tentunya bisa diminimalisir dengan adanya dukungan dari tokoh masyarakat seperti hasil penelitian Umayana dan Widya (2011), adanya dukungan tokoh masyarakat yang kurang, berpeluang 1,52 kali menyebabkan kader tidak aktif pada kegiatan Posbindu. Hal ini sesuai dengan hasil jawaban responden yang menunjukkan bahwa hanya sebagian kecil kader yang memiliki kedudukan di masyarakat $(6,5 \%)$, berpenghasilan tinggi $(8,7 \%)$ dan memiliki sisa uang untuk ditabung $(8,7 \%)$, sehingga dimungkinkan tidak adanya hubungan status sosial ekonomi dengan keaktifan kader. Keaktifan kader bisa jadi didorong oleh faktor lain seperti dukungan tokoh masyarakat dan penghasilan perbulan.

\section{Hubungan Lingkungan Keluarga dengan Keaktifan Kader Community TB Care 'Aisyiyah Surakarta}

Tidak terdapat hubungan antara lingkungan keluarga dengan keaktifan kader Community TB Care 'Aisyiyah Surakarta $(p=1,000)$. Hasil ini tidak sejalan dengan penelitian Umayana dan 
Widya (2011), yang menyimpulkan bahwa dukungan keluarga sangat berperan dalam mendorong minat atau kesadaran seseorang untuk mengikuti kegiatan posbindu ( $p$ value $=0,001)$. Peran keluarga memang sangat berpengaruh terhadap partisipasi masyarakat, jika anggota keluarga berperan positif, maka masyarakat akan berpartisipasi sesuai dengan sikap anggota keluarganya, begitu pula sebaliknya.

Tidak adanya hubungan antara lingkungan keluarga dengan keaktifan kader bisa jadi karena kurangnya partisipasi anggota keluarga untuk ikut peran kader dalam mensosialisasikan tuberkulosis. Hal ini sejalan dengan jawaban responden pada kuesioner yang menunjukkan rendahnya persentase dukungan keluarga terhadap kader dan partisipasi keluarga terhadap kader sebesar 50\%. Partisipasi menurut pengertian Mardikanto (2003), merupakan turut sertanya seseorang baik secara langsung maupun emosional dalam memberikan sumbangan-sumbangan terhadap proses pembuatan keputusan. Hal ini semakin jelas jika dikaitkan dengan karakteristik responden yang sebagian besar 42 responden adalah berjenis kelamin perempuan dengan pembagian peran kerja keluarga dimana laki-laki berperan mencari nafkah dan perempuan sebagai ibu rumah tangga sehingga laki-laki sedikit berpartisipasi dan mendukung untuk turut berperan menjadi kader.

Lingkungan keluarga memang merupakan lingkungan yang berpengaruh terhadap pengetahuan dan perilaku seseorang termasuk pula dalam hal keaktifan menjadi kader. Namun lingkungan keluarga tidak serta merta mempengaruhi keaktifan kader, yang mungkin dipengaruhi oleh faktor lebih spesifik seperti dukungan dan partisipasi suami terhadap aktifitas menjadi kader Community TB Care 'Aisyiyah serta keberadaan penderita TB di lingkungan keluarga.

\section{Hubungan Lingkungan Kerja dengan Keaktifan Kader Community TB Care 'Aisyiyah Surakarta}

Tidak terdapat hubungan antara lingkungan kerja dengan keaktifan kader Community TB Care 'Aisyiyah Surakarta $(\mathrm{p}=1,000)$. Hasil ini bertentangan dengan penelitian Fath (2015), yang menghasilkan lingkungan kerja non fisik berpengaruh positif terhadap kepuasan kerja karyawan hotel bintang dua di Yogyakarta ( $p$ value $=0,000)$. Begitu juga dengan Fitriyaningsih (2008), yang menyimpulkan lingkungan kerja dapat berpengaruh terhadap produktifitas pekerjaan yang dilakukan oleh pegawai. Sebenarnya, kondisi baik buruknya lingkungan kerja juga tergantung pada persepsi tiap karyawan. Persepsi inilah yang memotivasi karyawan dalam hal produktifitas kinerjanya.

Berbeda dengan penelitan Wibowo dan Erwi (2012), yang menunjukkan tidak adanya hubungan antara fasilitas di lingkungan kerja dengan keaktifan kader posyandu di wilayah UPT Puskesmas Ngembal Kulon. Dengan demikian berlaku pula pada tidakadanya hubungan antara lingkungan kerja dengan keaktifan kader yang bisa jadi karena ranah kerja kader lebih fleksibel dan hanya sesekali waktu berkunjung ke kantor Community TB Care 'Aisyiyah. Adapun keperluan berkunjung sekedar untuk menyetorkan data suspek ataupun data penderita TB, sehingga kader tidak secara langsung menikmati fasilitas di lingkungan kerja secara intens. Selain itu semua kader juga mendapatkan buku panduan kader, pelatihan dan berkesempatan sama untuk mengikuti pertemuan monitoring evaluasi yang diisi langsung oleh pengurus Community TB Care 'Aisyiyah dan kadang diisi oleh perwakilan dari dinas kesehatan Surakarta, tetapi tetap saja 
kader yang kurang aktif lebih banyak daripada kader yang aktif.

Tidak adanya hubungan antara lingkungan kerja dengan keaktifan kader juga akan melihat dari lamanya responden menjadi kader, yang berdasarkan pada karakteristik responden menurut tahun angkatan menjadi kader. Pada penelitian ini kader Community TB Care 'Aisyiyah terbagi menjadi beberapa angkatan. Angkatan tahun 2014 sebanyak 56,5\% responden dan angkatan 2015 sebanyak 43,5\% dengan 14 responden yang aktif $(19,7 \%)$ berasal dari angkatan 2014. Menurut Indrawan dan Chatarina (2014), semakin lama seseorang menjadi kader kesehatan maka akan semakin mudah memahami kondisi lingkungan sekitar termasuk pula mudah dalam mengidentifikasi dan mengajak suspek TB untuk berobat. Namun teori tersebut bisa jadi menjadi alasan ketidaknyamanan kader sebab adanya rasa bosan karena terlalu lama menjadi kader. Penelitian Awusi dkk (2009), menunjukkan tidak adanya hubungan yang secara statistik bermakna antara lama kerja dengan penemuan penderita TB paru $(p=0,16)$ yang berarti petugas TB dengan lama kerja $=2$ tahun atau $>2$ tahun memiliki peluang yang sama untuk berkontribusi menemukan penderita TB paru. Begitu juga dengan penelitian Sandayani (2011), yang menyimpulan bahwa semakin lama seorang menjadi kader bukan menjadi jaminan kader menjadi lebih baik dalam berperilaku menyampaikan informasi serta memberikan penyuluhan. Sehingga ada kemungkinan faktor lain yang mendorong keaktifan kader Community TB Care 'Aisyiyah Surakarta seperti faktor persepsi tentang penanggulangan bahaya TB oleh seluruh masyarakat, serta motivasi kader.

\section{KESIMPULAN}

Tidak ada hubungan antara pengetahuan dengan keaktifan kader Community TB Care 'Aisyiyah di Kota Surakarta (nilai $\mathrm{p}=1,000$ ).Ada hubungan antara keikutsertaan di 'Aisyiyah dengan keaktifan kader Community TB Care 'Aisyiyah di Kota Surakarta (nilai $\mathrm{p}=0,040$ ). Tidak ada hubungan antara status sosial ekonomi dengan keaktifan kader Community TB Care 'Aisyiyah di Kota Surakarta (nilai $\mathrm{p}=0,155$ ). Tidak ada hubungan antara lingkungan keluarga dengan keaktifan kader Community TB Care 'Aisyiyah di Kota Surakarta (nilai $\mathrm{p}=1,000)$.Tidak ada hubungan antara lingkungan kerja dengan keaktifan kader Community TB Care 'Aisyiyah di Kota Surakarta (nilai $\mathrm{p}=1,000$ ).

\section{DAFTAR PUSTAKA}

Amiruddin F., Indra FI., Muhammad AR., 2013, Implementasi Strategi AKMS Dalam Penanggulangan TB Paru Oleh 'Aisyiyah Muhammadiyah di Kota Makassar, Karya Tulis Ilmiah, FKM Unhas Makassar, Makassar.

Anggraini, S., 2015, Faktor-Faktor Yang Berhubungan Dengan Keaktifan Ibu Balita Dalam Kegiatan Posyandu Di Provinsi Lampung, Jurnal Kebidanan Adla Bandar Lampung. Vol 2, Edisi 2.

Awusi RYE., Saleh YD., Hadiwijoyo Y., 2009, Faktor-Faktor Yang Mempengaruhi Penemuan Penderita TB Paru di Kota Palu Provinsi Sulawesi Tengah, Berita Kedokteran Masyarakat, Vol 25, No 2. 
Depkes RI., 2012, Profil Kesehatan Profinsi jawa Tengah Tahun 2012, Jakarta.

Dinas Kesehatan Kota Surakarta., 2015, Situasi TB Kota Surakarta, Bidang P2PL, Surakarta.

Farhat, Y., 2012, Faktor-Faktor Yang Berhubungan Dengan Keaktifan Kader Posyandu Di Wilayah Kerja Puskesmas Pelabuhan Kota Banjarmasin, Al 'Ulum. Vol 54, No.4.

Fath, RA., 2015, Pengaruh Lingkungan Kerja Non Fisik Dan Karakteristik Pekerjaan Terhadap Kepuasan Kerja; Studi Pada Karyawan Hotel Bintang Dua Di Yogyakarta, Skripsi, Fakultas Ekonomi UNY, Yogyakarta.

Fitriyaningsih, N., 2008, Hubungan Antara Lingkungan Kerja Dengan Produktifitas Karyawan, Skripsi, Fakultas Psikologi Universitas Muhammadiyah Surakarta, Surakarta.

Hongsragon P., 2016, Medical Apology, Charansanitwong Printing Co, Bangkok.

Indrawan, IBMD., Chatarina U., 2014, Hubungan Pengetahuan Serta Dukungan Keluarga Dengan Peran Kader Dalam Pencapaian UCI Kelurahan, Jurnal Berkala Epidemiologi. Vol 2, No 1.

Kementerian Kesehatan Republik Indonesia., 2015, Rencana Pembangunan Jangka Menengah 2015-2019, Kementerian Kesehatan Republik Indonesia, Jakarta.

Mardikanto., 2003, Redefinisi Penyuluhan, Puspa, Jakarta.

Mintjelungan, M., 2011, Hubungan Status Sosial Ekonomi dan Keaktifan Belajar Terhadap Prestasi Belajar Mahasiswa Jurusan Pendidikan Teknik Elektro Konsentrasi Pendidikan Informatika Fakultas Teknik UNIMA, Vokasi Jurnal Pendidikan dan Kejuruan. Vol 2, No 1.

Moeloek, N D., 2015, Yang Tersembunyi Bahaya. Community TB Care 'Aisyiyah: Berita Komunitas Peduli TB Edisi XIV, Juni 2015.

Notoatmodjo, S., 2005, Promosi Kesehatan Teori Dan Aplikasi Press, PT Rineka Cipta, Jakarta.

Principal Recipient TB Care 'Aisyiyah., 2014, Agenda 2014 Beramal dan Bekerja untuk Bebaskan TB di Indonesia, Community TB Care 'Aisyiyah, Jakarta.

Sandayani, RA., 2011, Lama Menjadi Kader, Frekuensi Penelitian, Pengetahuan Gizi, dan Sikap Kader Posyandu dengan Perilaku Penyampaian Informsi Tentang Pesan Gizi Seimbang, Skripsi, Universitas Diponegoro, Semarang.

Sari, A., 2015, Hubungan Antara Tingkat Sosial Ekonomi Dengan Sanitasi Lingkungan Di Asrama Polisi, Pendidikan Geografi IKIP Veteran, Semarang. 
Suhat dan Ruyatul H., 2014, Faktor-faktor Yang Berhubungan Dengan Keaktifan Kader Dalam Kegiatan Posyandu Studi Di Puskesmas Palasari Kabupaten Subang, Jurnal Kesmas. Vol 10, No 1, 2014.

Suryati B., 2013, Faktor-Faktor Yang Berhubungan Dengan Keaktifan Kader Posyandu Dalam Penanggulangan Diare Balita, Poltekes, Jakarta.

Umayana HT., Widya HC., 2011, Dukungan Keluarga Dan Tokoh Masyarakat Terhadap Keaktifan Penduduk ke Posbindu Penyakit Tidak Menular, Jurnal Kesmas. Vol 11, No 1.

Wibowo E., Erwin RD., 2012, Faktor-Faktor Yang Berhubungan Dengan Keaktifan Kader Posyandu Di Wilayah UPT Puskesmas, Cendekia, Vol 2, No 2.

Wijaya IMK., Bhisma M., Putu S., 2013, Hubungan Pengetahuan, Sikap, dan Motivasi Kader Kesehatan Dengan Aktivitasnya Dalam Pengendalian Kasus Tuberkulosis di Kabupaten Buleleng, Jurnal Magister Kedokteran Keluarga. Vol 1, No 1, 2013.

World Health Organization., 2015, Global tuberculosis laporan 2015, WHO. 